\title{
Circuit
}

Musiques contemporaines

\section{Hockey Noir}

\section{Keiko Devaux}

Volume 28, numéro 2, 2018

URI : https://id.erudit.org/iderudit/1051297ar

DOI : https://doi.org/10.7202/1051297ar

Aller au sommaire du numéro

\section{Éditeur(s)}

Circuit, musiques contemporaines

\section{ISSN}

1183-1693 (imprimé)

1488-9692 (numérique)

Découvrir la revue

\section{Citer ce compte rendu}

Devaux, K. (2018). Compte rendu de [Hockey Noir]. Circuit, 28(2), 106-107.

https://doi.org/10.7202/1051297ar

Ce document est protégé par la loi sur le droit d'auteur. L'utilisation des services d'Érudit (y compris la reproduction) est assujettie à sa politique d'utilisation que vous pouvez consulter en ligne.

https://apropos.erudit.org/fr/usagers/politique-dutilisation/ 


\section{Hockey Noir}

Keiko Devaux

The Ensemble contemporain de Montréal (ЕСM+), under the passionate artistic direction of Véronique Lacroix, marks its zoth anniversary with the genre breaking graphic opera, Hockey Noir, by André Ristic with libretto by Cecil Castelluci. The opera premiered in Montreal on May $3^{\text {rd }}$ and $4^{\text {th }}$ at the MonumentNational and will travel to Toronto in a co-presentation with Continuum and the Toronto Comic Arts Festival, then later to Belgium at the end of 2018. The ECM+ has always distinguished itself through strong focus on multi-disciplinary productions, pushing and blurring boundaries and expectations. Hockey Noir embraces this approach and takes it one step further. At first glance, the combination of hockey, projected graphics, and contemporary music might seem like a stark mismatch. Yet this highly contrasting counterpoint of influences, all under the aesthetic and mood of film noir, very successfully creates a seamless and contrasting experience of comical satire and crime drama. The film noir approach serves as the common base for the music, libretto, staging, illustrations and costume design to come together cohesively.

This project was jointly initiated by the composer André Ristic and librettist Cecil Castelluci, both former Montreal residents now living abroad, who had previously collaborated with the ECM+ on the first graphic opera Les Aventures de Madame Merveille, along with stage director Marie-Josée Chartier. Taking inspiration from the real life and tragic disappearance of Toronto Maple Leafs' player Bill Barilko following their Stanley Cup win in the 1950s, they began

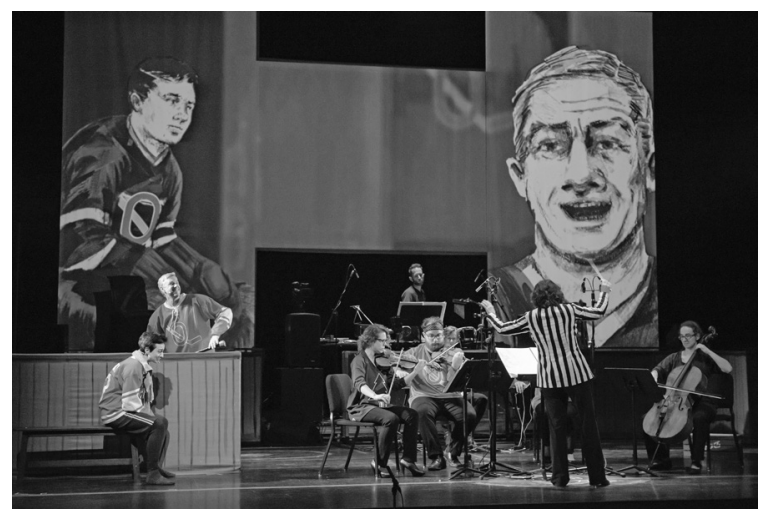

Solistes: Pascale Beaudin, soprano et Michiel Schrey, ténor. Véronique Lacroix, direction. ECM+, 6 musiciens. Opéra d'André Ristic (Hockey Noir, créé au Monument-National à Montréal le 3 mai 2018). Crédit: Maxime Boisvert

imagining fictitious plot lines around this event. While Ristic and Castelluci share an enthusiasm for hockey, Castelluci and invited illustrator Kimberlyn Porter share a passion for film noir. Kimberlyn Porter's more "hands on" approach to film noir poster design is brought to life with Serge Maheu's video design in numerous projections on a screen in the shape of an "H" for hockey. These projections not only serve to accompany the narrative, but also as extensions of the narrative and the characters on stage.

Like the sport depicted, this multi-disciplinary production involves two different teams. However, whereas in the sport they are competing, in this production the off-stage creators and collaborators, composer, librettist, stage director, illustrator, video, costume, and lighting designers, all work together not to complicate or crowd, but to amplify the players on stage. With a string quartet, (Lizann Gervais, Hubert Brizard, Marie-Lise Ouellet, Chloé Dominguez), piano/synthesizer (Pamela Reimer), and percussion (Benjamin Duinker) centre stage, the cast of four soloists, soprano (Pascale Beaudin), mezzo (Marie-Annick Béliveau), 
tenor (Michiel Schrey), and baritone (Pierre-Étienne Bergeron) move around the four corners of the stage as if playing simultaneously on our sense of quadrants, in a comic strip, or the corners of a hockey rink. This ingenious stage design allows the cast to move around dynamically on stage as the drama unfolds, all the while keeping the musicians at the centre of the action. Off stage, it is the narrator and detective (Jean Marchand) who reveals the behind-the-scenes details. This detective perspective serves as the first clear reference to film noir as the story and plot focus on the investigation of crime, corruption, jealousy and the general colourful underbelly of hockey in the 1950s.

The story centres around four main characters: Bigowsky/Gal Friday (Beaudin), the young talented hockey star for the Montréal Quabs, Lafeuille (Schrey), a hockey player at the close of his career and determined to win the cup, Romanov (Bergeron), a mob boss hedging bets on the game, Madame Lasalle (Béliveau), Romanov's lover but rebellious to his aims, plus Detective Loiseau (Marchand), the voice-off that investigates the disappearance of Bigowsky. The opera is structured in four acts, with the fourth acting as "overtime," and with a running time of 80 minutes loosely paralleling hockey regulation playtime of three periods followed by overtime. The plot quickly establishes Bigowsky's desperate situation: blackmailed by Romananov, he must lose the game, in direct conflict with his friend and teemate Lafeuille who is intent on crowning his career with a Cup victory. This impossible situation leads to his disappearance, disguising himself as a woman, Gal Friday, who then continues to support his friend from the stands. Further complicating this dramatic situation is the love between Bigowsky and Lasalle, adding many twists and turns to the plot, both astonishing and true to the clichés of the form, peppered with lies, betrayals, greed, and passion.

The feat of creating a cohesive and dynamic composition to this highly ambitious, multidisciplinary and polyvalent work was no easy one. André Ristic rises to the challenge with humour, drama, and most importantly an emphasis on the lyrical quality of the work. The work shifts focus between, and superposes seamlessly, more classical contemporary textures, sharp gestures, and dynamic rhythmic play with the sound of the hockey arena organ, and the general sonic landscape of the sport: the puck hitting the ice, the skates and sticks against the ice, and even the Zamboni. It evokes the live quality and ritual of listening to hockey on the radio; with the play-by-play of action given by our narrator overtop a bed of sonic activity and environmental sounds. As the story depicts the famous rivalry between the Montreal Canadians and the Toronto Maple Leafs, here represented as the fictitious Montréal Quabs and Toronto Pine Needles, the rich dynamic nature of the libretto and music, and much of the humour, springs from the multi-lingual approach of the libretto. The interplay between French, English, Franglais, and Joual provides a rich bed of inspiration for both the libretto and musical lyricism. Here we see the collaboration with graphic novel illustrator Porter serve to further underline the humour in these quickpassing witticisms as well as the surtitles, as we see equally in graphic novels and operas.

From the entrance of the conductor, Véronique Lacroix, dressed as a hockey referee, and of the six musicians wearing the two fictitious teams' jerseys to an operatic air of censored profanities by Romanov, this work is punctuated with very playful and rebellious humor. However, it is by no means a light or frivolous work. The intense talent and finesse put into the rich and contrasting tapestry of sounds of the ECM+ ensemble along with four talented and very dynamically contrasting soloists is not eclipsed by the comedy, or in the visual collaborations. It is the polyvalent ambition of this graphic opera that makes it so delightfully surprising and successful. 